\title{
"Adapt to the need of the production line adaptive social" building research and practice of applied talents training system
}

\author{
Jing Bai ${ }^{1, a}$,Yanxia Song ${ }^{1, b}$,Dejun Liu ${ }^{1, c}$ and Huida Duan ${ }^{1, d}$ \\ ${ }^{1}$ School of jilin, Beihua University, Jilin 132021, China; \\ ajlbyj@163.com, b309972666@qq.com, cdejunliu@126.com,dhuida_duan@163.com
}

Keywords: Applied talents; Training system; The production line.

\begin{abstract}
Based on local engineering applied undergraduate cultivating talent poor adaptability, engineering application ability is not strong. So we study the engineering background can be incorporated into the whole course of teaching philosophy. To realize the seamless docking adaptive social needs of personnel training goal, we should make knowledge, ability and quality training combine with classroom lesson, the integration of theory and practice, pay attention to the application of knowledge, and translated into ability. For the local engineering applied undergraduate talents cultivation quality, provides the theory basis of the reform and practical achievements .
\end{abstract}

\section{Introduction}

In view of the actual provincial local applied undergraduate talents training, cultivate university graduates though many years of engineering practice whose ability is weak, poor and independent working ability is not strong, the overall quality is not higher many don't adapt to China's economic construction and social development. In order to adapt to the requirements of the new situation, applied undergraduate students after graduation whose most of the people to the reality of the job market to promote the education teaching reform continued to deepen, the features and solve engineering students upon graduation can realize the goal of "seamless docking" and enterprise requirement. For the region's economic construction and social development to create more solid basis, strong ability to adapt and good comprehensive quality, and competitive qualified applied senior specialized talents, colleges and universities in China to study the applied talent cultivation system to build the "adaptive social demand for production line" of the applied talents cultivation system, and a breakthrough in practice and improve.

\section{The research situation, level and development trend at home and abroad}

Foreign talent training mode, the United States and Germany model is more successful.Higher education in the United States is one of the features of high development level, the education popularization degree is high, the "general (encyclopedic man)" education mode, as a result of the recent emphasis on "return to a project", systematic and practical features of outstanding engineering practice to improve the competitiveness of its industrial products in the world.Germany is a prominent industrial countries which the target of engineering undergraduate education is to cultivate well-trained engineers and to adopt the "pure" education mode. In our country undergraduate education is affected by the different both patterns, although have train and bring up the tens of millions of scientists and engineers in the team and all kinds of specialized personnel. Our country is a developing country, under the condition of planned economy, the former Soviet union's "know-how" education model, the influence of has obtained certain achievement.At present, the rapid rise of economic power has enabled our country's higher education from elite education to popular education,training mode and sharp. The contradiction between social needs in the engineering education of the whole higher education system in our country occupies the largest proportion (about $80 \%$ or so) from the survey data, therefore, with the success or failure of the reform of China's industrial technology progress and the development of science and technology relations . Require starting from the actual situation of our country solve the problem of talent cultivation system. 
Based on the applied undergraduate colleges and universities curriculum system, outline of research, at the same time in jilin, liaoning, Shanghai, hubei and other provinces. Cities of large enterprise to talented person's demand research, combining with the actual situation of our school, come to the conclusion that:

1) Social and enterprise need to have "practice ability is strong, the load on the, has the development potential and broad scope" characteristics of talents.

2) Enterprise expectations of applied talents jobs are: it is creative to solve practical problems in the production of the first line. Generally to the requirement of talent innovation is a theoretical innovation, and pay more attention to talent in "technology integration, transplant technology, implementation of" in the process of innovation ability.

3) Colleges cultivate the students lack of engineering background, engineering consciousness and can solve practical engineering problems with the requirements of the enterprise.

4) Knowledge economy to the requirements of higher engineering education, sets up the new concept of engineering education, cultivation of all-round development of knowledge, strong practical ability, high comprehensive quality, innovative and certain innovation ability, the applied senior specialized talents to adapt to the social development.

By the development of China's industrial and engineering technology of the practical need of determines the higher engineering education in China should be to cultivate well-trained engineers of the basic goal is the objective need. Undergraduate research and development can apply the training of engineering and technical personnel is mainly engaged in production of the first line of the design, manufacture, operation, construction, testing, technical guidance, such as work, focus is geared to the needs of production of the first line. Therefore, looking for social (enterprise) needed to suit a point with the school personnel training and the corresponding curriculum system construction is the key to improve the quality of personnel training.

\section{Production line adaptive social demand oriented applied talents cultivation system}

To realize the seamless docking adaptive training objectives and social needs. We can build "for the production line automatically to adapt to the society" of the applied talent cultivation system and build "production line automatically to adapt to the society" oriented applied innovative talent training system, realize the goal of seamless docking in the training system automatically adapt to social.

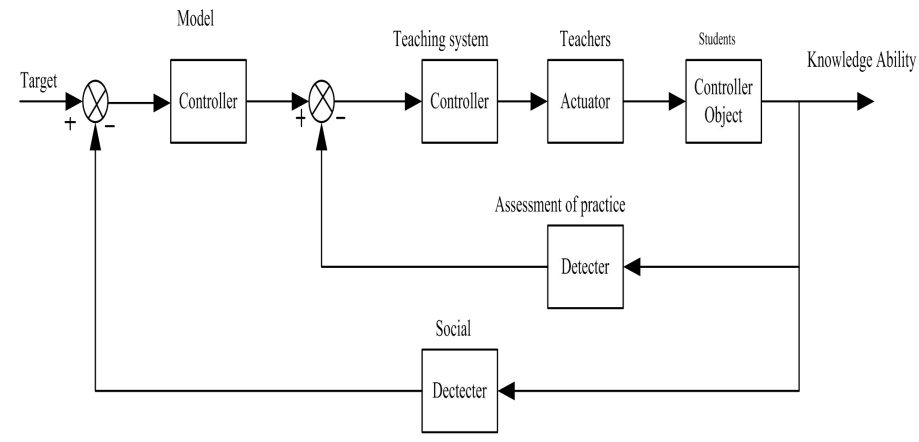

Fig 1. Engineering core competence electrical information talent cultivation system

As a given target we can enterprise production line requirements, through the outer social and unit of choose and employ persons of the detector is to adjust the training plan, and accesses the unfairness, the practice of assessment and students through the campus of detector to adjust the teaching system of each link, by teachers. Teaching materials and experiment equipment function to the students of the object, and the training of students which is suitable for production of a line of knowledge, ability and quality unified seamless docking with the enterprise of high quality engineering applied talents. Teaching system block diagram is shown in figure 1. 


\subsection{Teachers' abilities in engineering application}

Most of the young college teachers from school to school whose lack of practical experience and the rich theory foundation. Therefore, strengthen the training education of young teachers teaching ability and the ability to solve the problem of the engineering practice is the key to improve the teaching quality.

1) To strengthen the teachers' professional development ability and make teachers to adapt to the development of science and technology in their own professional field.

2)Cooperation with industry to make teachers on production line for on-the-spot professional practice activities. In order to understand what they teach specialized or related specialized current production, service, management, management of technology, processes, equipment, idea and so on. The status development trend.

3) Lead the students and guide students in industry production internship;

4) Hired experienced enterprise personnel part-time job of teaching to enrich the teachers' team.

3.2 The construction of practical teaching system and the base

1)Build the campus training and practice base :

According to the requirement of the professional education training goal and teaching features, we should gradually set up to cultivate students' basic competence and skills, professional and technical application ability and professional skills and comprehensive practical ability and comprehensive ability of laboratory and combination of campus practice and practice base in the real environment to cultivate the students' engineering consciousness to improve the students' engineering application ability, cultivate students' innovation spirit and team consciousness.

2)The construction of practical teaching content and system:

Through the education platform course learning phase, the practice teaching of the course experiment and training as the main body, the experiment is given priority to with verification, comprehensive program, courses and professional courses in professional large plane phase. To experiment, professional practice and course design as the main body, the experiment is given priority to with comprehensive, design and innovation; Graduation practice and graduation design and engineering practice together; Add engineering projects, the new technology course, series of comprehensive practice curriculum, series of comprehensive practice curriculum practice, and the combination of enterprises and scientific research to achieve the teaching purpose of seamless and social demand. To strengthen the construction of engineering practice base and the laboratory and provide safeguard to realize engineering education.

3)Relying on off-campus practice base:

Moving the classroom into the factory, the enterprise introducing college, cooperation between colleges and enterprises technical backbone to participate in the whole process of talent training. The teachers and students to participate in the whole process of production of the enterprise, strengthen personnel training and enterprise to produce zero distance, professional teaching and the depth of the enterprise production.

\subsection{Construction of the curriculum group}

As the main line of course group to build a number of engineering application and system development. As the core we can make each group with a comprehensive and practical engineering technology and with the corresponding application practice class, to a certain extent, to realize the seamless connection between colleges.

3.4 The teaching management

1)Intensify the teaching monitoring, timely find problems in a timely manner, to ensure the implementation of the teaching process.

2)Enhance the management of the examination link can promote the formation of good style of study, improve the teaching quality. 


\section{Cultivate the students}

To participate in national, provincial and other kinds of the competition and the surface of the award-winning, student employment rate above 90\%, employment areas and levels increased significantly; Students one's deceased father grind level increased significantly, provincial colleges and universities, used to be $85 \%$ now for 211 and 985 colleges and universities.

\section{Summary}

Engineering application ability training as the core to build and practice oriented production line adaptive social needs of personnel training system.

Teachers in their professional field satisfies the requirement of the development of science and technology whose the basis of cultivating students with their engineering application abilities.

Practice base hardware conditions is the means to realize students' engineering application ability training.

Engineering awareness throughout the whole teaching process is the way to realize students' engineering application ability training.

\section{References}

[1] Mingyi Wang. Take time mission to create China's higher education an applied university [J]. China's higher education, 2014, 21:34 to 37.

Reference to a book:

[2] Ye Fang. Highlight excellence Set up to promote local applied talents in colleges and universities to cultivate [J]. China's higher education, 2014, 15, blessed to 37.

[3]LijunYang . Research and practice of application oriented undergraduate talent training model for electrical engineering and automation [J]. Journal of Liaoning Institute of Science and Technology.2014,06-15.

[4] Min Liu , the problems and Countermeasures of higher engineering education personnel training mode [J]. Journal of Yancheng Institute Of Technology (SOCIAL SCIENCE EDITION), 2007, (1): 79-83.5.

[5]Louis G,castonguag,Aaron L,pincus,Andrew A, McAeavey.Practice research network in a psychology training clinic:Building an infrastructure to foster early attachment to the scientific-practitioner model [J].Taylor\&Francis.2015,01.

[6] Mingxian Shi. For the United States engineering education reform in twenty-first Century [J]. Chinese university teaching, 2002, (10): 39-41.

\section{Author introduction}

Jing Bai , female $(1965,1)$, Ph.D., university of north China, dean of the school of electrical and information engineering, provincial teaching masters, and national comprehensive reform pilot project director, national characteristics, head of the professional brand, in the first professional director, director of the provincial college of science and technology innovation practice demonstration base.

National comprehensive reform pilot project: ZG0119

Jilin province education science "twelfth five-year" plan project: GH150062 
Emil:jlbyj@163.com 